\author{
Julia Mazurkiewicz-Sułkowska \\ Katedra Języków Specjalistycznych \\ oraz Komunikacji Międzykulturowej \\ Uniwersytet Łódzki \\ juliamaz100@yahoo.com
}

\title{
JĘZYK PRACOWNIKÓW SEUŻB SPECJALNYCH W POLSKIEJ RZECZPOSPOLITEJ LUDOWEJ I W BUEGARSKIEJ REPUBLICE LUDOWEJ (NA PRZYKEADZIE ANALIZY TECZEK TW „BOLEK” I TW „SABINA”)
}

Informacje zgromadzone $\mathrm{w}$ archiwach służb specjalnych okresu komunizmu od prawie trzydziestu lat pozostają $\mathrm{w}$ centrum zainteresowania opinii publicznej krajów dawnego „bloku socjalistycznego”. Tzw. teczki są też stałym elementem rozgrywek politycznych, a ich upublicznianie budzi ogromne emocje i kontrowersje. Pisane wówczas donosy i notatki służbowe są jednocześnie częstym tematem analiz historyków i archiwistów. Trudno jednak znaleźć kompleksowe badania języka, którym się charakteryzowały. Istnieją jedynie krótkie mini-słowniczki wywiadu PRL (Paczkowski 2004) oraz opinie - choćby tłumaczy Lecha Wałęsy (A.M. Mydlarskiej i W. Kubińskiego) - komentujące język donosów. Wynika z nich, że autorami tekstów zawartych w dokumentach niekoniecznie są bezpośrednio osoby, którym teksty te są powszechnie przypisywane. W opinii tłumaczy Wałęsy materiały zawarte w tzw. teczce Kiszczaka nie mogły być przygotowane przez przyszłego prezydenta, ponieważ pisane są językiem, który Wałęsie był zupełnie obcy (zob. Kubiński, Mydlarska 2017). Opinie te pokazują, że język teczek służb specjalnych powinien być zbadany nie tylko przez archiwistów i historyków, ale także językoznawców. Wypełnienie tej luki badawczej może pomóc w odpowiedzi na wiele interesujących pytań: czy język donosów tworzy odrębny gatunek w ramach administracyjnej odmiany języka prawniczego, czy może też szeroko pojętej lingwistyki sądowej? czy osoby piszące donosy zachowywały swój idiolekt, czy też zmieniały styl na 
potrzeby „zadania”? czy istnieje możliwość ustalenia autentyczności teczek na podstawie konfrontacji tekstów donosów z idiolektem osoby podejrzewanej o współpracę? czy pracownicy UB posiadali swój technolekt, a jeśli tak, jakie były jego cechy? Wszystkie te pytania można de facto podzielić na dwie grupy: 1) o język osób donoszących (przekazujących informacje) i 2) o język pracowników służb specjalnych. Z pewnością ciekawe wnioski mogłaby przynieść analiza konfrontatywna, polegająca na porównaniu języka donosów w różnych krajach byłego bloku socjalistycznego.

Niniejszy artykul jest próbą analizy języka pracowników służb specjalnych $\mathrm{w}$ aspekcie konfrontatywnym, na przykładzie dwóch teczek z krajów „demoludów" - Polski i Bułgarii. W obydwu krajach dyskusja o współpracy osób zaufania publicznego z komunistycznymi służbami specjalistycznymi jest bardzo gorąca. W Polsce niewątpliwie największe emocje wzbudziło ujawnienie teczki byłego prezydenta Lecha Wałęsy (domniemany TW „Bolek”), zaś w Bułgarii podobnym echem odbiła się informacja o istnieniu teczki chyba najbardziej znanej bułgarskiej (a dokładniej, bułgarsko-francuskiej) intelektualistki Julii Kristevej (domniemany TW „Sabina”), która jest niekwestionowanym autorytetem w filozofii, psychoanalityce i semiotyce. Obie teczki wywołały tak duże zainteresowanie publiczne, że zostały upublicznione w Internecie. Zarówno Wałęsa, jak i Kristeva zaprzeczają współpracy i twierdzą, że teczki są sfałszowane. Udostępnione opinii publicznej dokumenty nie mogą jednak stanowić podstawy do analizy (zwłaszcza konfrontatywnej) języka tajnych współpracowników z wielu powodów. Przede wszystkim nie ma pewności, że donosy są autentyczne, nie można też porównywać języka niewykształconego przedstawiciela związków zawodowych z językiem władającej kilkoma językami i wykładającej na najlepszych światowych uniwersytetach intelektualistki, poza tym teczka Kristevej nie zawiera ani jednego tekstu pisanego czy dyktowanego i podpisanego przez nią osobiście. W jej teczce są wyłącznie notatki służbowe sporządzone przez oficera prowadzącego rozmowy. Teczki te jednak dają możliwość porównania idiolektów specjalistycznych pracowników służb specjalnych w dwóch państwach bloku wschodniego.

\section{Teczka personalna tajnego wspólpracownika o pseudonimie „Bolek”}

Teczka jest sporządzona przez 3 pracowników i jednego rezydenta, co jest zaznaczone w podsumowującym akta dokumencie. Język pracowników służb przeprowadzających rozmowy - z osobą początkowo pozyskiwaną, a następnie TW - którzy sporządzali notatki służbowe, arkusze kontroli oraz charakterystyki 
tajnego współpracownika, charakteryzuje styl, który można nazwać prawniczo-administracyjnym, z właściwymi językowi urzędów państwowych formami bezosobowymi, szablonowością i standardowością. Czytając materiały sporządzone przez pracowników SB, nie mamy wątpliwości, że jest to rodzaj języka specjalistycznego, $\mathrm{w}$ dużym stopniu sterminologizowanego, o czym świadczą bardzo częste konstrukcje z frazą określającą w postpozycji, np. „lat ok. 21”, „w godzinach wieczornych”. Jest to typowy dla polszczyzny szyk przy terminologizacji pojęcia wyrażonego połączeniem rzeczownika z przymiotnikiem (np. „rumianek zwyczajny”/„zwyczajny rumianek”) (zob. Mazurkiewicz-Sułkowska 2014). Dokładniejsza analiza dokumentu pozwoliła na wyodrębnienie również następujących cech.

Właściwe językowi urzędowemu skróty: tj. „w/w” oraz sformułowania „w dniu”, „w dniu dzisiejszym”, „wobec zaistniałej sytuacji”, „w wyniku”, „wobec powyższego”, „na skutek”, „w związku z (powyższym)”, „,biorąc pod uwagę”, np.

W/w obrał pseudonim «Bolek».

W/w plotka b. szybko „obiegła” stocznię.

W dniu dzisiejszym przeprowadzilem rozmowę operacyjną z ...

Na skutek informacji o wkroczeniu MO na teren stoczni i zbliżenia się wojska do bram.

W związku z powyższym nawiązałem kontakt z Wałęsą.

Biorąc pod uwagę jego aroganckie zachowanie się zaniechałem dalszej rozmowy.

Bardzo duże nasycenie tekstów typowymi dla języka i stylu administracyjnego konstrukcjami analitycznymi zawierającymi frazę znominalizowaną: „celem odbycia”, „celem uwolnienia”, „celem poproszenia”, „celem omówienia”, ,celem zdobycia”, „w wypadku nie dojścia”, „w celu wywołania”, „z zamiarem zobaczenia", np.

Udali się wraz z nimi do miasta celem uwolnienia więźniów.

W wypadku nie dojścia do spotkania planowanego T.W. będzie do mnie dzwonił. W celu wywołania spotkania podałem mu poprzednio swój numer telefonu służbowego.

Działał on z aktywem wypadków grudniowych celem zdobycia u nich lepszego zaufania.

Wyszedł ponownie do miasta z zamiarem zobaczenia co dzieje się na mieście.

Wysoka frekwentywność form biernych i bezosobowych: „został zwolniony”, „został wybrany”, „zostaną uwolnieni”, „zaczęto krzyczeć”, „zaczęto rzucać”, „miano przedstawić”, „została zwrócona”, „został doprowadzony”, „przeprowadzono rozmowę”, „przeprowadzono szereg rozmów”, „dokonano wyboru”, np. 
Z tłumu zaczęto krzyczeć, że jest to przebrany milicjant.

Załoga ustaliła listę postulatów, którą miano przedstawić w dyrekcji.

... w godzinach wieczornych został doprowadzony do Kom. Woj. M.O. w Gdańsku, gdzie przeprowadzono z nim szczegółową rozmowę...

Przeprowadzono z nim szczegółowe szkolenie na którym pouczono go jak ma zachowywać się w swoim środowisku.

Po każdym jego wystąpieniu przeprowadzono z nim rozmowę podczas której wytykano mu jego niewłaściwe wystąpienie na zebraniu, pouczano jak ma zachowywać się oraz ostrzegano go, że o ile będzie nadal tak postępował, to zostanie zwolniony z zakładu.

W dniu 11.02.1976 na Wydz. W-4 Stoczni Gdańskiej im. Lenina odbyło się zebranie związkowe, na którym dokonano wyboru nowych władz związkowych.

Odwrócony szyk w połączeniach czasownik w czasie przeszłym + imiesłów bierny: „przyjęty został”, „wysłuchany został”, „pozyskany został”, „wytypowany został”, np.

Do pracy w Stoczni Gdańskiej przyjęty został dnia 17.05.1967.

Referat o wytycznych wysłuchany został «na śpiąco».

Wymieniony pozyskany zostal doraźnie w dniu 22.12.1970.

...z ramienia ustępującej Rady Oddziałowej wytypowany został jako delegat na konferencje Rady Zakładowej.

Uwagę zwraca również wysoka częstotliwość użycia spójników „gdyż”, „iż”, „ażeby”, „lecz”, „aby”, „oraz”, np.

Stwierdził, że komendant przyrzekł mu, iż więźniowie zostaną uwolnieni.

W tym momencie kierownik Wydziału oznajmił, ażeby wybrać spośród załogi...

Treść komunikatu nawoływała aby nie wychodzić z terenu stoczni gdyż nastąpią aresztowania by nie dać się sprowokować gdyż mogą być zastrzeleni.

Kolejną cechą charakterystyczną jest bardzo częste użycie czasownika „udać się”, np. „Udał się do manifestującego tłumu”, „Udał się w kierunku stoczni”.

Do określenia osób w aktach są użyte następujące określenia: „osobnik”, „obywatel”, „towarzysz”/,tow.”, „jednostka”, np.

Ten sam osobnik ogłosił przez megafony... Jest to osobnik w wieku lat ok. 35.

Obywatel Wałęsa zgodził się z moim stanowiskiem.

Znał numer telefonu do tow. Serwacińskiego.

Dał się poznać jako jednostka zdyscyplinowana i chętna do współpracy.

Wykorzystywany był jako jednostka sygnalizacyjna. 
Często pojawia się również określenie anaforyczne „wymieniony”/„wyżej wymieniony”, np. „Wymieniony tłumaczył, że...”, „wymieniony zwrócił się do dyrektora...."

Sporadycznie w tekście pojawiają się regionalizmy lub kolokwializmy, typu „na holu”, „na zakładzie”, „dla tłumu”. Użycie konstrukcji „dla + dopełniacz” zamiast celownika może świadczyć o kresowym pochodzeniu oficera prowadzącego, np.

Na holu znajdowało się bardzo dużo rannych milicjantów.

... na zakładzie nic się nie dzieje.

...pokazał dla tłumu w oknie kilka osób...

Z powyższego wynika, że w aktach TW „Bolka” mamy wiele cech języka administracyjno-urzędowo-prawniczego. Jest to przykład języka stosunkowo poprawnego, a poza dość licznymi błędami interpunkcyjnymi tylko sporadycznie pojawiają się błędy ortograficzne, np. „Stara się iść najkrutszą trasą”.

\section{Teczka personalna tajnego współpracownika o pseudonimie „Sabina”}

Teczka Julii Kristevej jest pisana przez dwóch pracowników służb specjalnych: osoby prowadzącej, która jest autorem wszystkich notatek służbowych oraz oficera nadzorującego przebieg sprawy i regularnie piszącego opinie oraz wskazówki co do dalszego postępowania z tajnym współpracownikiem.

W odróżnieniu od teczki TW „Bolka” teczka TW „Sabiny” ma bardzo mało cech języka prawniczo-administracyjnego. Co prawda w tekście pojawiają się zarówno formy bierne i zwrotne: са помучени, се повтарят, се дава („оtrzymano", „powtarzają się”, „daje się") - Аосега от агент «Сабина» са получени две информачии ${ }^{1}$ (ttum. „Dotychczas od agenta «Sabina» otrzymano dwie informacje"), Не се дава обаче обща оченка от резултатите на проведения семинар („Nie daje się jednak ogólnej oceny wyników przeprowadzonego seminarium”), jak i nominalizacje: с цел указване давление („w celu wywarcia nacisku”) - ...с цел указване давление на съдебните власти... („... w celu wywarcia nacisku na władze sądownicze...”), ale ich frekwentywność jest bardzo niska i absolutnie nie wplywa na odbiór tekstów jako administracyjno-prawniczych.

${ }^{1}$ W związku ze specyfiką analizowanych bułgarskich materiałów (bardzo dużą ilością błędów językowych, wyrazów gwarowych itd.), w niektórych przypadkach zrezygnowano z tłumaczenia tekstu źródłowego, a tam, gdzie go przetłumaczono, w miarę możliwości zachowano oryginalną stylistykę, ortografię i interpunkcję. 
Sporadycznie pojawia się fraza в резулmam на („w wyniku” - ...в резултат на което ряско се увеличили тяхните последователи, ... в резултат на много интензивната им пропаганда ( „... w wyniku czego gwałtownie zwiększyła się ilość ich zwolenników”, „...w wyniku ich bardzo intensywnej propagandy”).

Jedynymi markerami urzędowości tekstów z teczki TW "Sabiny” są określania anaforyczne: същият/същзата, горепосочените („wspomniany”, „wyżej wymienieni”) - Същият взел отрищателно становище, Същият често посещавал Кайло, ...след приемане на същата в ООН..., ... заедно с горепосочените образували така наречената интелектуално-философска надорганизационна ръководна група... („Wspomniany zajął odmienne stanowisko”, „Wspomniany często odwiedzał Kailo”, „... po przyjęciu wspomnianej do ONZ...”, „... wraz z wyżej wymienionymi mieli stworzyć tak zwaną intelektualistyczno-filozoficzną grupę...”) oraz stosunkowo często używane konstrukcje imiesłowowe, co jest obce ogólnej odmianie języka, gdzie tego typu formy właściwie się nie pojawiają. W języku bułgarskim użycie imiesłowu przysłówkowego zawsze jest połączone z dążeniem do nadania przekazowi bardziej intelektualnego i oficjalnego charakteru. Jako przykłady opisanych form w teczce Sabiny można przytoczyć następujące użycia imiesłowów: заявявайки, атакувайки, обвинявайки, изполуввайки („оświadczając”, „atakując”, „oskarżając”, „wykorzystując”):

Най-силно влияние имали привьржениците на Социализма, които осъждали ОАР за сътрудниество със САЩ защото приела плана Роджьрз, залвявайки, че нито ОАР, нито Сирия са соииалистически страни... (Najmocniejszy wpływ podobno mają zwolennicy Socjalizmu, którzy jakoby osądzają ZRA za współpracę z USA, ponieważ przyjęły one plan Rogersa, oświadczając, że ani ZRA, ani Syria nie są krajami socjalistycznymi...).

...в същото време засилили антисъветската пропаганда, атакувайки СССР nо следните въпроси... (...w tym samym czasie mieli nasilić propagandę antyradziecką, atakując ZSRR w następujących kwestiach...).

...критикували при свои изказвания политиката на Китай, обвинявайки го, ие сътрудничи повече с официялната реакиионна френска политика [...podobno krytykują w swoich wypowiedziach politykę Chin, oskarżając je w tym, że bardziej wspólpracują z oficjalną francuską polityką reakcyjną).

...mърсела пьтища за популяризиране на старата китайска култура използувайки по-доброто разположение на китайското рбководство... (...podobno szukała dróg popularyzacji starej kultury chińskiej wykorzystując lepsze nastawienie władz chińskich...).

Do określania osób są używane wyłącznie източник („źródło”) i агенm (,agent”), np. 
Средата в която работи и живее източникът е именно интелектуална., Източникът видял едно писмо... (Środowisko w którym mieszka i pracuje źródło jest właśnie intelektualne...).

Източникът не знае поименно собствениците и издателите... (Źródlo nie zna z imienia i nazwiska właścicieli i wydawców...).

Задачи на източника не можем да поставим, защото от двете свобщения не се виждат възможностите му (Zadań źródłu nie możemy powierzyć, dlatego że te dwie wiadomości nie pokazują jego możliwości).

Аосега от агент «Сабина са получени две информаиии (Dotychczas od agenta «Sabina» otrzymano dwie wiadomości).

Jak już wspomniałam, lektura teczki TW „Sabina” pod kątem językowym absolutnie nie przypomina lektury teczki TW „Bolek”. Teczka Kristevej prawie nie ma cech języka urzędniczego, natomiast wyróżnia ją coś innego - wręcz gigantyczna nieudolność językowa oficera prowadzącego. Ilość błędów gramatycznych, ortograficznych, stylistycznych i interpunkcyjnych jest tak duża, że samo ich wymienienie i klasyfikacja wystarczyłyby na odrębne opracowanie. Jako dominujące można wymienić:

- łączna pisownia nie z czasownikami: Неможал мично да присъствува..., ...че немогат да приемат тази книга за продажба..., ... немогъм да намери друго облснение...;

- użycie form rodzajnika długiego w miejscu rodzajnika krótkiego: Освен източниквт от френска страна били поканени още следните мица...;

- nieuzasadnione użycie $\breve{u} \mathrm{w}$ rzeczownikach liczby mnogiej: Преглед на положението на свойте сънародници..., ... студенти и ученици както във висиите учебни заведения, така и в гимназийте...;

- notoryczna pisownia -ия- $\mathrm{w}$ wyrazach pochodzenia obcego: Изнесение данни са известни в голямата си част от официялни източници, ... сътрудничи повече с официялната реакционна френска политика, ... а се организира сббиране на материялни средства за подпомагане на Палестинското революиионно движение, ... получи материяли за Аимитьр, ... често дава место на материяли на страниците на списанието..., На левичарските организачии и по-специялно на маоистите... ;

- $\quad y \mathrm{w}$ miejscu nieakcentowanego i zredukowanego poprzez podniesienie artykulacji „o”: ... с иел указване давление на съдебните власти...;

- brak jakiejkolwiek konsekwencji $\mathrm{w}$ formach $\mathrm{z}$ kontynuantem dawnej „jaci”. Niektóre formy są zgodne z zasadą przegłosu w bułgarskim języku literackim (alternacja „a/e” w miejscu starej „jaci”), ale kilkanaście razy

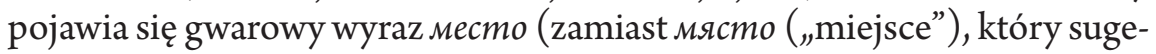
ruje zachodniobułgarskie pochodzenie osoby piszącej i jest klasycznym 
błędem mieszkańców Sofii i okolic, np. ... често дава место на материями на страниците на списанието..., В своето кредо китайците слагали на пьрво место развитието на отноченията със социалистическите страни, на второ место с развитите капиталистически страни и на трето место с развиващите се страни, На практиката развитието на отношенията със социалистическите страни отивало на трето место. W dalszej części tekstu pojawia się jednak forma mıxнume (zamiast техните - „ich”), która już zupełnie nie jest właściwa dialektom zachodnim, nр. ...в резултат на което ряско се увеличили тяхните последователи в резултат на много интензивната им пропаганда.

Uwagę zwracają również rusycyzmy typu ocoбняא („willa”) - Просmoрен особняк в Париж... („Przestronna willa w Paryżu”) i duża liczba potocyzmów i kolokwializmów, jak np. ^yднища („dom wariatów” / "wariatkowo”) - Чe в СССР били създадени мудниии в които се затваряли интектуалии („Że w ZSRR podobno są stworzone domy wariatów w których są zamykani intelektualiści”).

Lektura teczki TW „Sabiny” sprawia wrażenie zbioru tekstów pisanych językiem bardzo ogólnym, z nielicznymi markerami administracyjno-prawniczymi. To styl osób o bardzo niskiej kulturze językowej, które nie mają opanowanych podstawowych zasad językowej poprawności. Zdumiewa wręcz fakt, że do rozmów z intelektualistką pokroju Kristevej był oddelegowany ktoś o tak niskich kompetencjach językowych. Oficer prowadzący nie był nawet w stanie poprawnie napisać dziedziny, którą zajmuje się przesłuchiwane przez niego „źródło” i zamiast семиотика („semiotyka”) napisał семеоmика („semeotyka”).

Osobnym zagadnieniem wartym analizy językoznawczej, zwłaszcza w ramach językoznawstwa sądowego, jest zbadanie stopnia przekonania pracowników służb specjalnych co do prawdziwości otrzymanej informacji. $\mathrm{W}$ odpowiedzi na to pytanie mogą pomóc wykładniki modalności epistemicznej w tekstach pisanych przez pracowników SB. Przez modalność epistemiczną rozumiem tu ocenę prawdziwościową informacji udzielanych przez tajnych współpracowników, inaczej mówiąc, stopień przekonania piszącego co do prawdziwości wygłaszanego przez TW sądu (zob. Grzegorczykowa 2001: 121-136). Ponieważ opisywane w notatkach służbowych treści zazwyczaj są wtórnymi komunikatami, mamy tu do czynienia również z renarracją, opisywaną w literaturze często jako ewidencjalność. Przy czym niektórzy autorzy podkreślają, że już samo kodowanie faktu otrzymania informacji z drugiej ręki zdejmuje z nadawcy odpowiedzialność za prawdziwość przekazywanego sądu, wobec czego wykładnik użycia interpretatywnego naturalnie jest jednocześnie 
wykładnikiem oceny epistemicznej (zob. Holvoet 2011: 86). Dla potrzeb niniejszego artykułu będę posługiwała się terminem „modalność imperceptywna”, łączącym zarówno renarrację (ewidencjalność), jak i rezerwę prawdziwościową (modalność epistemiczną). Jak zaznaczają autorzy Gramatyki konfrontatywnej bułgarsko-polskiej (Korytkowska, Roszko 1997), parafraza zdania imperceptywnego zawiera co najmniej dwa zdania, których predykaty odnoszą się do co najmniej dwóch aktów informacyjnych - aktualnego i pierwotnego: „X powiedział, że Y powiedział, że Z, ale X nie jest pewien, że Z”.

Strukturę semantyczną zdania imperceptywnego - czyli zdania zawierającego jednocześnie renarrację i rezerwę prawdziwościową - realizują na płaszczyźnie powierzchniowej obydwa języki. Zarówno w języku polskim, jak i bułgarskim służą do tego wykładniki leksykalne typu: podobno, rzekomo, jakoby, вероятно, може би, сигурно. Partykuły modalne występujące $\mathrm{w}$ zdaniach imperceptywnych zostały już niejednokrotnie poddane analizie językoznawczej (zob. Czapiga 2005; Honowska 1984; Puk 2013). Poza tymi leksykalnymi markerami język bułgarski posiada również osobne formy narratywne, czyli formy tzw. trybu nieświadka (несвидетелско наклонение, преизказно наклонение). Bułgarskie formy narratywne mogą być użyte przy jednoczesnym spełnieniu dwóch warunków: renarracji i rezerwy prawdziwościowej, a użytkownik języka w swojej wypowiedzi zawsze musi się ustosunkować co do prawdziwości wypowiadanej treści, ponieważ każdy z dziewięciu bułgarskich czasów ma odrębną formę dla modalności indykatywnej i odrębną dla modalności imperceptywnej. Dodatkowo rezerwa prawdziwościowa może być podkreślona poprzez wzmocnioną formę narratywną lub za pomocą leksemu yж. Nie dziwi więc fakt, że przy takim bogactwie form modalność imperceptywna jest w tym języku szybko „wyłapywana” przez użytkowników i badaczy języka. Ci ostatni podkreślają, że tryb nieświadka, nazywany często żartobliwie trybem plotkarskim po 1989 roku stał się jednym z wyznaczników poziomu prasy na rynku bułgarskim (im bardziej poważne medium, tym rzadziej spotykają się w nim formy narratywne). Warto tu podkreślić, że formy te są wyjątkowo rzadko spotykane w bułgarskim języku prawniczym i administracyjnym.

W języku polskim dla oddania modalności imperceptywnej, poza leksykalnemu wykładnikami typu „podobno”, „jakoby”, „rzekomo”, służy również paramaroflogiczna konstrukcja "mieć” + bezokolicznik. Nie należy tej konstrukcji mylić z homonimiczną konstrukcją „mieć” + bezokolicznik, wyrażającą modalność irrealną (zob. Nowakowska 2017), np.

- imperceptywność (renarracja + rezerwa prawdziwościowa) - „X powiedzial, że Y powiedzial, że Z, ale X nie jest pewien, że Z”. „Prezydent miasta miał dać łapówkę, w rzeczywistości jednak płacił za piwo”; 
- irrealność (charakter przeciwfaktywny) - „X wie, że P nie zostało spełnione, X przypuszczał, że P zostało spełnione”. „Już miała powiedzieć, że raz się żyje, ale przypomniała sobie, że w jej przypadku to nie do końca prawda”.

Analiza badanych teczek pod kątem wyrażania modalności imperceptywnej przyniosła bardzo ciekawe rezultaty. Teczka TW „Sabiny” zaskakuje tym, że jest prawie w 90\% napisana w trybie nieświadka. Formy narratywne zdecydowanie dominują we wszystkich notatkach służbowych, np.

На източника направило голямо впечатление почти неприкритата борба за надмощие на този симпозиум между привьржениците на Алжир и ОАР в Палестинското движение, но немогъл да намери друго обяснение освен борбата за водачество на арабския свят между рбководителите на тези две страни (Na źródle podczas sympozjum miała wywrzeć duże wrażenie prawie nieukrywana walka o przewagę między zwolennikami Algierii i ZRA w sprawie kwestii palestyńskiej, lecz podobno nie mogło ono znaleźć innego wyjaśnienia niż walka pomiędzy przywódcami tych krajów o przywództwo w świecie arabskim).

На симпозиума присъствували повече от 200 души на издрбжка на Емира на Кувейт, който преследвал две иели... (Na sympozjum podobno było obecnych około 200 osób, będących na utrzymaniu Emira Kuwejtu, który mial prześladować dwa cele...).

Można by podejrzewać, że pracownik bułgarskich służb specjalnych używał form narratywnych wyłącznie ze względu na ich funkcję renarracyjną, zerując jednocześnie rezerwę prawdziwościową. Dokładniejsza analiza materiału nie potwierdza jednak tej tezy, ponieważ w momentach braku rezerwy prawdziwościowej, przy zachowaniu renarracji, agent decydował się na formy rezultatywnego czasu perfectum, np.

Източникът е пребивавая от 13 до 28 февруари т.г. в Близкия изток и участвувал в симпозиума по Палестинския въпрос организиран в Кувейт под патронажа на Емира на страната... (Źródło przebywało od 13 do 28 lutego b.r. na Bliskim wschodzie i podobno brało udział w sympozjum dotyczącym kwestii palestyńskiej pod patronatem Emira kraju...).

Analiza powyższego zdania pokazuje, że oficer prowadzący nie ma wątpliwości co do pobytu TW w okresie od 13 do 28 lipca na Bliskim Wschodzie, natomiast pozostała informacja (o uczestnictwie w sympozjum) jest już wyrażona formami narratywnymi. Perfect, który daje właśnie możliwość renarracji bez jednoczesnej rezerwy prawdziwościowej, pojawia się w tekstach niezwykle rzadko. 
Analogiczna sytuacja jest w zdaniu:

Официялно френското правителство не пречело на развиваната от двамата палестински предствители дейност и даже проявило жест и им разрешило да наемат малко помещение за свой клуб, в който източникът още не е имал възможност да отиде (Oficjalnie rząd francuski podobno nie przeszkadza rozwijanej przez dwóch palestyńskich przedstawicieli działalności i nawet $\mathrm{w}$ ramach ukłonu miał pozwolić wynająć małe pomieszczenie dla swojego klubu, do którego źródło jeszcze nie miało możliwości pójść).

Interesujące jest to, że często formy rezultatywnego perfectu są poprzedzone frazami podkreślającymi pewność przekazywanej informacji, tak jak w następującym zdaniu, gdzie forma perfectum jest poprzedzona stwierdzeniem „źródło posiada wiedzę, że...”:

На източника е известно че са били поканени видни общественици (Źródłu jest znane, że zostali zaproszeni wybitni społecznicy).

Analiza teczki TW „Bolka” pod kątem form imperceptywnych prowadzi do analogicznych wniosków. W tekście polskim bardzo często pojawiają się wykładniki rezerwy prawdziwościowej, które zaskakują tym bardziej, że teczka TW „Bolka”, jak wspomniano, ma wiele cech języka prawniczo-administracyjnego, a wykładniki imperceptywności absolutnie nie są temu stylowi właściwe. Ich wysoka frekwentywność pokazuje, jak bardzo autor notatek służbowych chciał podkreślić własną rezerwę prawdziwościową. W tekstach są użyte zarówno wykładniki leksykalne, jak i paramorfologiczna konstrukcja „mieć” + bezokolicznik:

- markery leksykalne: „Nazwisk stoczniowców, którzy brali udział w maltretowaniu milicjantów, Wałęsa rzekomo nie zna”, „Do 3-osobowego kolektywu wszedł również Wałęsa L. który rzekomo nie zna dwóch pozostałych osób”, „Wśród załogi rozpowszechniane były plotki jakoby wojsko, które obstawiło stocznię jest radzieckie lub czeskie...";

- Paramorfologiczna konstrukcja: „Wałęsa L. mial zapytać dyrektora co robić w tej sytuacji”, „Dyrektor odpowiedzial, aby...”, „Na tę propozycję funkcjonariusz mial wyrazić zgodę i ją zaaprobował".

Czasami potrzeba podkreślenia rezerwy jat tak duża, że oficer prowadzący używa form wzmocnionych, złożonych zarówno z wykładnika leksykalnego, jak i konstrukcji „mieć” + Inf.:

Po odbiciu karty zegarowej Wałęsa L. opuścił stocznię i udał się do domu skąd mial rzekomo nigdzie nie wychodzić. 
Komendant miał rzekomo przyrzec, że więźniowie zostaną uwolnieni.

Wówczas funkcjonariusz w cywilu miał rzekomo zapytać Wałęsę jakie widzi on rozwiązanie.

Dyrektor mial rzekomo przyznać, że nie będą pociągani do odpowiedzialności lecz na piśmie tego nie przedstawił.

Podsumowując całość rozważań, można stwierdzić, że pomimo bardzo dużych różnic stylistycznych i językowych między dwiema teczkami jedna rzecz je niewątpliwie łączy - dążenie pracowników służb specjalnych do podkreślenia własnej rezerwy prawdziwościowej co do przekazywanych przez tajnych współpracowników treści. Fakt ten zadziwia tym bardziej, że zarówno w teczce TW „Bolka”, jak i TW „Sabiny” źródła są oznaczone jako „zaufane”. Językowa analiza jednak temu zaprzecza.

\section{Bibliografia}

Czapiga Z. (2005), O funkcji modalnej leksemu можеm/może w języku rosyjskim i polskim, „Slavia Orientalis”, nr 2, s. 271-281.

Grzegorczykowa R. (2001), Wprowadzenie do semantyki językoznawczej, Warszawa.

Holvoet A. (2011), O leksykalnych wykładnikach użycia interpretatywnego, „Linguistica Copernicana”, nr 1(5), s. 77-91.

Honowska M. (1984), Prawdopodobnie (przyczynek do teorii aktu mowy), „Polonica”, nr 10, s. 121-131.

Korytkowska M., Roszko R. (1997), Gramatyka konfrontatywna bułgarsko-polska 6. cz. 2 Modalność imperceptywna, Warszawa.

Korytkowska M., Koseska-Toszewa V., Roszko R. (2007), Polsko-butgarska gramatyka konfrontatywna, Warszawa.

KubińskiW., Mydlarska A.M. (2017), Nowa linia obrony Wałęsy. „Językz donosów nie jest w jego stylu. On nie mówit jak milicjant!", https: //telewizjarepublika. $\mathrm{pl} /$ nowa-linia-obrony-walesy-quotjezyk-z-donosow-nie-jest-w-jego-styluon-nie-mowil-jak-milicjantquot,44789.html (dostęp: 14.02.2020).

Mazurkiewicz-Sułkowska J. (2014), Słowiańska terminologia techniczna (na materiale polskim, rosyjskim i bułgarskim), Łódź.

Nowakowska M. (2017), Interpretacja prospektywna peryfrazy 'mieć + bezokolicznik', „Bulletin de la Société polonaise de Linguistique”, t. LXXIII, s. $221-246$. 
Paczkowski A. (2004), Bardzo krótki stownik wywiadu, „Biuletyn IPN”, t. 4, nr 11(46), s. 67-70.

Puk M. (2013), Rosyjski wykładnik modalności epistemiczneј очевидно i jego polskie oraz angielskie odpowiedniki, „Przegląd Rusycystyczny”, nr 1(141), s. 116-132.

Julia Mazurkiewicz-Sułkowska

\title{
LANGUAGE OF EMPLOYEES OF THE COMMUNIST-ERA STATE SECURITY SERVICE IN THE POLISH PEOPLE'S REPUBLIC AND THE PEOPLE'S REPUBLIC OF BULGARIA (BASED ON AN ANALYSIS OF "BOLEK” AND "SABINA" COLLABORATORS FILES)
}

\author{
(Summary)
}

Releasing declassified files, reports, denunciations and other Communist-era secret service documents in the former socialist countries raises great controversies and emotions. The socalled "teczki" become an element of political maneuvering and power games. Reports from the informants and collaborators are usually the object of consideration for historians and archivists alike. However, there are virtually no linguistic analyses that characterize them. The paper is an attempt to investigate the language of secret service employees from a comparative perspective based on two collections of notes from Poland and Bulgaria.

Key words: language of secret services, language of denunciations, secret service files, Polish People's Republic, People’s Republic of Bulgaria 